\title{
Adult education history in Britain: past, present and future (part II)
}

\author{
Mark Freeman \\ UCL Institute of Education, London, England \\ M.Freeman@ucl.ac.uk
}

This article - the second part of a two-part contribution - offers a number of suggested directions for the historiography of adult education in Britain. It identifies opportunities to address longstanding areas of neglect that have been overshadowed by a focus on the 'Great Tradition' of adult education. Although a key theme of recent research is a shift in focus from educational institutions to the study of learners and learning, the article argues that there remains considerable scope for the study of adult education organisations, and identifies four specific areas of opportunity: the examination of the governance of educational institions, the study of the publications of students and teachers, biographical studies of learners and learning, and geographical and spatial analyses. All these approaches are being productively adopted, and they offer opportunities to draw historians of adult education closer to other developments in modern social, economic and cultural historiography.

Keywords: adult education, history, historiography, Britain

The first part of this article ${ }^{1}$ argued that the historiography of adult education in Britain is breaking free of the shackles of the 'Great Tradition' that Malcolm Chase identified in his important review of the state of the field in $1995 .^{2}$ A wider range of educational institutions and processes are being studied, with publications challenging the boundaries of adult education and demonstrating the range of relationships that its historians can productively engage in. Here, in the second part, I explore some of the possibilities that exist for the further development of the field. I begin by identifying some areas of adult education in the past that remain relatively neglected in comparison to the 'Great Tradition', and then consider four ways in which the historiography of adult education might further develop in the future with examples of how these approaches are being productively adopted, often at the boundaries between the history of education and the wider economic, social and cultural history of modern Britain. There is also a transnational aspect to this: although my focus here is not mainly on transnational histories of education, there are opportunities to develop this area of research further, and some of these are pointed out in what follows. I begin, however, with the traditional attempt to find 'gaps' in the literature.

\section{'Aspects of neglect'}

It is worth emphasising the ongoing need, even within the area of non-vocational education, for more studies that range beyond the 'Great Tradition' and its offshoots. Recent historical interest in the educational work of women's citizens' associations, the settlement movement, adult schools and the co-operative movement all suggests a broadening of historiographical focus, with Roger Fieldhouse's so-called 'auxiliaries' coming closer to the mainstream of

\footnotetext{
${ }^{1}$ REFERENCE TO PART I OF ARTICLE.

2 Malcolm Chase, "Mythmaking and Mortmain"': The Uses of Adult Education History?', Studies in the Education of Adults, 27 (1995), 52-65.
} 
scholarship. ${ }^{3}$ Fresh interests and approaches, however, need to be justified: historians should not simply be engaged in 'retro-tourism' through past landscapes of adult learning. ${ }^{4}$ If we are considering a 'curious case' - to use Richard Clarke's description of the Selborne Lecture Bureau, the subject of an article in History of Education in 2010 - we need to explain, as Clarke does, its wider relevance as well as its intrinsic interest. ${ }^{5}$ To take the point further, Harold Silver argued in 1983 that historians of education should consider critically what he called 'aspects of neglect': why some stories, organisations and people are in the 'canon', and why others are not. An obvious example for Silver was the neglect of women's stories in the history of education, and much recent scholarship - though less so, perhaps, in the history of adult education than elsewhere - has addressed this 'silence', to which Chase also drew attention. ${ }^{6}$

There are, however, many other 'aspects of neglect', some of which arise from the focus and organisation of historical scholarship on adult education. A familiar example, mentioned in Part I of this article, ${ }^{7}$ will illustrate one of these aspects: the Adult Education Regulations of 1924, a landmark in the history of British non-vocational adult education. Most historians of education in Britain probably know that these regulations, introduced by the first Labour government, created 'Responsible Bodies' entitled to state funding for adult education provision. Most would also know that universities and Workers' Educational Association (WEA) districts became 'Reponsible Bodies'; and some might even know that the regulations applied to England and Wales only, and were not extended to Scotland until 1934. Probably far fewer, however, could name the other 'Responsible Bodies', although they can be ascertained quickly from Thomas Kelly's History of Adult Education in Britain: the National Council of YMCAs (Young Men's Christian Associations), the Welsh National Council of YMCAs, the National Industrial Alliance and the Educational Settlements Association (ESA). ${ }^{8}$ It is true that each of these, as funded 'Responsible Bodies', educated fewer adults than the WEA or the universities, but most were significant features of the adult education landscape during the interwar period. Yet historians rarely consider them and relatively little is known about them. This lack of knowledge is particularly striking in the case of the ESA - later the Educational Centres Association (ECA) - given its importance, and that of its prominent spokesmen, in the wider interwar and post-war politics and culture

\footnotetext{
${ }^{3}$ Roger Fieldhouse and associates, A History of Modern British Adult Education (Leicester: NIACE, 1996), chapter 12. See Part I of this article.

${ }^{4}$ Malcolm Chase, 'Stories We Tell Them? Teaching Adults History in a Postmodern World', Studies in the Education of Adults, 32 (2000), 97.

${ }^{5}$ Richard Clarke, 'Adult Education between the Wars: The Curious Case of the Selborne Lecture Bureau', History of Education, 39 (2000), 613-29.

${ }^{6}$ Harold Silver, Education as History: Interpreting Nineteenth- and Twentieth-Century Education (London: Methuen, 1983), 17-34; Chase, "Mythmaking and Mortmain"”, 61. There is a large literature on women in education: see for example Jane Martin (ed.), Women and Education: Major Themes in Education (4 vols, London: Routledge, 2011). On women and independent working-class education, see Valerie Yow, 'In the Classroom and not at the Sink: Women in the National Council of Labour Colleges', History of Education, 22 (2006), 181-96.

\section{${ }^{7}$ REFERENCE TO PART I.}

${ }^{8}$ Thomas Kelly, A History of Adult Education in Great Britain (Liverpool: Liverpool University Press, 1970 [1st ed. 1962]), 276-7. Kelly notes that the University Council of Music and 'certain residential colleges' later became 'reponsible bodies' (see also p. $339 \mathrm{n}$. $3)$.
} 
of adult education. There is only one book-length history of the ECA, an 'insider' account published more than 50 years ago, ${ }^{9}$ and, similarly few studies consider the educational work of the YMCA and other organisations. This is partly due to the tendency, which Chase noted, of historians of adult education themselves to come from within the 'Great Tradition', and to investigate their own corner of the field. Historians' political allegiances have also played a role: John Field has remarked that 'most late twentieth century adult education historiography was profoundly sympathetic to radicalism and Marxism', and hence focused on 'workers' education'.${ }^{10}$ Other, more conservative, forms of non-vocational provision have attracted much less attention in the standard histories of adult education. Moreover, some areas of 'workers' education' itself feature less heavily in the historiography than might be warranted: the co-operative movement is a good example. As Pushpa Kumbhat has recently emphasised, the interwar co-operative Central Education Committee devoted some $£ 200,000$ annually to education, 'a sum far higher than either the WEA or NCLC [National Council of Labour Colleges] could dream of acquiring'. ${ }^{11}$ Kumbhat's doctoral thesis examines co-operative education alongside the 'Great Tradition' and independent working-class adult education in Yorkshire, usefully bringing together strands of adult education that tend to be considered separately. ${ }^{12}$

As the case of the YMCA emphasises, a notable 'silence' in today's historiography concerns religious adult education. Most historians would recognise the importance of religious or religiously inspired adult education in the nineteenth century, but for the twentieth century it is largely overlooked. (Deirdre Raftery has suggested that this marginalisation of religion happens in most history of education. ${ }^{13}$ Here we can return to the familiar story of the 'Responsible Bodies'. It is widely known that the NCLC rejected any involvement with this form of state support, in favour of continuing to promote working-class education that was independent of both the Board of Education and the universities. Indeed, the NCLC would not have been offered the opportunity in any case. Yet it is less often pointed out that other, larger organisations did not apply for 'Responsible Body' status: one example was the National Adult School Union (NASU), which preferred to maintain its independence as a religious adult education provider. When the 'Responsible Bodies' were first designated in 1924 the NASU had more than three times as many members as the WEA $(51,917$ versus 17,131$)$ and also considerably more than the NCLC (which had 38,011 in 1925-6). ${ }^{14}$ Adult schools were already in decline by this time, and continued to shrink rapidly

\footnotetext{
${ }^{9}$ A. J. Allaway, The Educational Centres Movement: A Comprehensive Survey (London: NIACE, 1961).

${ }^{10}$ John Field, “'Spiritual Values in Adult Education” (1925) by Basil A. Yeaxlee', in Wegweisende Werke zur Erwachsenenbildung, ed. Ralf Koerrenz, Elisabeth Meilhammer and Käthe Schneider (Jena: Paideia, 2007), 287.

${ }^{11}$ Pushpa Kumbhat, 'Learning Together? The Co-operative Union, the Workers' Educational Association and the National Council of Labout Colleges 1918-1939', Journal of Cooperative Studies 49 (2016), 9. On the NCLC, see Part I, 000-00.

${ }^{12}$ Christine Pushpa Kumbhat, 'Working Class Adult Education in Yorkshire 1918-1939' (unpublished PhD thesis, University of Leeds, 2017). On the co-operative movement, see for example Keith Vernon, 'Co-operative Education and the State c.1895-1935', Forum, 55 (2013), 293-307.

${ }^{13}$ Deirdre Raftery, 'Religions and the History of Education: A Historiography', History of Education, 41 (2012), 52.

${ }^{14}$ Kelly, History of Adult Education, 273. The NCLC figures are from J. P. M. Millar, The Labour College Movement (London: NCLC Publishing Society, 1979), 252, and are the sum
} 
thereafter, and this has contributed to their marginalisation within the historiography of adult education; however, this marginalisation is unwarranted by their contemporaneous significance and size. Although they featured prominently in J. F.C. Harrison's Learning and Living, published in 1961 - Harrison proposed various reasons for the movement's decline twentieth-century adult schools were discussed only very briefly in Kelly's 1962 history, and even less in Fieldhouse's historical survey of $1996 .^{15}$

In a similar vein, just as some historical research itself becomes canonical, other important contributions are neglected and forgotten. In 1925 Basil Yeaxlee published a twovolume study, Spiritual Values in Adult Education, based on his University of London doctoral thesis; this included a substantial historical account of religious adult education. ${ }^{16}$ Like Kelly and Fieldhouse, Yeaxlee was both a historian and a practioner, but not in university adult education: he had been secretary of the YMCA's wartime adult education committee and a member of the Ministry of Reconstruction's influential Adult Education Committee of 1919, and in the 1920s was secretary of the ESA. Yeaxlee was a central participant in national and international debates on adult education and social service, ${ }^{17}$ but few are now familiar with his historical work on adult education, despite various attempts to revive interest in it. ${ }^{18}$ This is perhaps even more surprising given the revival of religious adult education in new guises in recent years. Although the Christian influence undoubtedly declined during the mid-twentieth century, it never went away, and in 1986 John Elias noted a growth in scholarly activity in the area, much of it originating in the USA. ${ }^{19}$ Recent developments suggest a revival of religious adult education in Britain and elsewhere. One of the most significant phenomena in this repsect has been the rapid growth of the Alpha course: in 2013 it was claimed that 2.8 million people in Britain had taken the course since it was first run in 1977. These figures compare with 'more than 2 million' who have studied at the Open University (according to its website), and 'more than 70,000' who study annually with the WEA. ${ }^{20}$ And these are just within the Christian denominations: there is even less historical study of adult education in other religious traditions. The history of religious adult

of the students in its classes, day and weekend schools, and postal courses. The figures for the nearest available years either side, 1922-3 and 1928-9, were considerably lower.

${ }^{15}$ J. F. C. Harrison, Learning and Living 1790-1960: A Study in the History of the English Adult Education Movement (London: Routledge, 1961), 308-11; Kelly, History of Adult Education, 260-1; Fieldhouse and associates, History of Modern British Adult Education, 261, 382.

${ }^{16}$ Basil A. Yeaxlee, Spiritual Values in Adult Education: A Study of a Neglected Aspect (2 vols, London: Oxford University Press, 1925).

${ }^{17}$ Stuart Marriott, 'Yeaxlee, Basil Alfred (1883-1967)', Oxford Dictionary of National

Biography (Oxford: Oxford University Press, 2004):

http://www.oxforddnb.com/view/article/63843 (accessed 20 January 2019).

${ }^{18}$ John Elias, 'Basil Yeaxlee: Educator of Adult Spirituality', British Journal of Religious Education, 7 (1985), 104-11; Field, "'Spiritual Values"”.

${ }^{19}$ John Elias, 'Adult Religious Education: An Academic Sub-Discipline', Studies in the Education of Adults, 18 (1986), 11-17.

${ }^{20}$ Tabatha Leggett, 'Inside Alpha: An Atheist's Foray into Christianity', New Statesman, 20 June 2013: http://www.newstatesman.com/religion/2013/06/inside-alpha-atheists-foraychristianity; Open University, 'Facts and Figures':

http://www.open.ac.uk/about/main/strategy-and-policies/facts-and-figures; WEA, 'Learn with Us': https://www.wea.org.uk/learn-us (all accessed 20 January 2019). A lower figure of 1.2 million was given for the Alpha course in the Independent, 31 March 2013. 
education, then, is one area that would certainly benefit from further investigation. It is particularly surprising that so little research has been done on the YMCA's educational work, despite the existence of a large body of archival material. ${ }^{21}$

Part of what I am suggesting here is a consideration of neglected adult education institutions, and this might seem to run against the grain of the shift in focus from providers to learners that has produced so much valuable research in recent years. ${ }^{22}$ Woodin, for example, has welcomed historians' move away from institutions, remarking that 'while researching educational institutions has distinct advantages in terms of definition and clarity, such studies can only be enriched by placing them alongside the diverse range of learning processes that may be taking place at any one time' ${ }^{23}$ Chase, in 1995, called for a similar shift. ${ }^{24}$ However, we should not overlook the importance of this history of educational institutions: indeed, in 1995 Chase himself noted a number of lacunae which have still not been filled two decades later, including histories of the Royal Society of Arts and the City and Guilds Literary Institute. Some of Chase's 'silences' have since been partly addressed, for example by studies of the educational work of women's organisations such as the Women's Co-operative Guild and Women's Institutes - yet there remains scope for much more research in this area. ${ }^{25} \mathrm{~A}$ lot of adult learning takes place within and around educational institutions, many of which have left full, and still largely under-used, archival records. It is often impossible to escape formal organisations, which have a tendency to come into focus even when historians try to look beyond them. From Catherine Feely's article on the builder's labourer Frank Forster, for example, we learn that this young man, although self-taught in some respects, nevertheless attended WEA and NCLC classes, as well as Left Book Club meetings and the Chester branch of the Communist Party. ${ }^{26}$ These institutions provided him with a social life (albeit a limited one), and with a formal political context for the discussion of ideas, thus helping him to shape his understanding of the books that he read independently. As Ursula Howard has recently emphasised, the term 'autodidact' is misleading, because most of the people whom we so designate actually learned in more or less organised groups, at least some of the time. ${ }^{27}$ Even the most 'informal' education often emerges from, or

\footnotetext{
${ }^{21}$ There are 55 linear metres of material in the archive of the National Council of YMCAs, held at the Cadbury Research Library, University of Birmingham, XYMCA.

${ }^{22}$ See Gary McCulloch and Tom Woodin, 'Towards a Social History of Learners and Learning', Oxford Review of Education, 36 (2010), 133-40

${ }^{23}$ Tom Woodin, 'Working-Class Education and Social Change in Nineteenth- and TwentiethCentury Britain', History of Education, 36 (2007), 491.

${ }^{24}$ Chase, "Mythmaking and Mortmain"”, 60. REFERENCE TO PART I.

${ }^{25}$ Ibid., 54. See Valerie Wright, 'Education for Active Citizenship: Women's Organisations in Interwar Scotland', History of Education, 38 (2009), 419-36; Alice Kirke, 'Education in Interwar Rural England: Community, Schooling and Voluntarism' (unpublished PhD thesis, University College London, 2017); Caitriona Beaumont, Housewives and Citizens: Domesticity and the Women's Movement in England 1928-1964 (Manchester: Manchester University Press, 2015).

${ }^{26}$ Catherine Feely, 'From Dialectics to Dancing: Reading, Writing and the Experience of Everyday Life in the Diaries of Frank P. Forster', History Workshop Journal, 69 (2010), 94, 102-3.

${ }^{27}$ Ursula Howard, Literacy and the Practice of Writing in the 19th Century: A Strange Blossoming of Spirit (Leicester: NIACE, 2012), 113-36.
} 
develops, an institutional context: examples from recent historiography include the Selborne Lecture Bureau and the Federation of Worker Writers and Community Publishers. ${ }^{28}$

In turning from education to learning, then, we should be wary of overlooking the importance of institutions, although we do need to write their history in terms of wider social and political processes. As Chase admitted, '[t] here will still be a place for institutional histories, where these are self-critical and alive to the problematics of ethnic, gender and power relations' ${ }^{29}$ There are some good recent examples of critical, contextualised and engaging histories of single institutions, such as Tom Steele's centennial history of Swarthmore Educational Centre in Leeds and Cynthia Brown's sesquicentennial study of Vaughan College, Leicester. ${ }^{30}$ Marcella Sutcliffe's work on the Working Men's College shows the potential for linking institutional histories to wider intellectual currents, and could be a model for future work on the many national and international organisations that await sustained historical investigation. ${ }^{31}$ Among these are the ECA, the NASU, the British Institute of Adult Education, the World Association of Adult Education, the National Federation of Community Associations and, as noted, the YMCA, not to mention many individual educational centres and literary institutes, residential colleges, WEA districts and branches, mechanics' institutes, working men's colleges, adult schools, regional organisations, churches, trade unions, political parties and pressure groups. ${ }^{32}$ Moreover, the history of independent working-class education has by no means been exhausted, given the extensive records of the NCLC that are available in the National Library of Scotland, the London School of Economics, and elsewhere. ${ }^{33}$ It is not necessary - indeed, it would probably be undesirable - for for each of these organisations each to find a single historian to 'fill the gap' by writing their history. It is often the links between them and their wider role in communities that gives their history its richness and value. Nevertheless, all of them have had some significance within adult education at various times during the past two centuries, and all have left archival records that are available for critical exploitation. In relation to higher education, Silver has called for 'more comprehensive and less parochial and antiquarian

${ }^{28}$ Clarke, 'Adult Education between the Wars'; Tom Woodin, Working-Class Writing and Publishing in the Late-Twentieth Century (Manchester: Manchester University Press, 2018).

${ }^{29}$ Chase, "Mythmaking and Mortmain"”, 61.

${ }^{30}$ Tom Steele, Swarthmore's Century: A Leeds Experiment in Adult Education (Leeds: Swarthmore Education Centre, 2009); Cynthia Brown, A Blessing to the Town: 150 Years of Vaughan College, Leicester (Leicester: University of Leicester Institute of Lifelong Learning, 2012).

${ }^{31}$ Marcella Pellegrino Sutcliffe, 'The Origins of the "Two Cultures" Debate in the Adult Education Movement: The Case of the Working Men's College (c.1854-1914)', History of Education, 43 (2014), 141-59.

${ }^{32}$ There are practitioner histories of the ECA and NASU, but neither provides the critical detachment and wider context that are needed. There has also been some published research on the social and educational work of the YMCA, though this remains surprisingly modest in scope. See Allaway, Educational Centres Movement; W. Arnold Hall, The Adult School Movement in the Twentieth Century (Nottingham: Nottingham University Department of Adult Education, 1985); Neal Garnham, 'Both Praying and Playing: "Muscular Christianity" and the YMCA in North-East County Durham', Journal of Social History, 35 (2001), 397 407.

${ }^{33}$ NCLC records 1904-1970, National Library of Scotland, manuscript collections, Acc.5120; NCLC records 1921-64, London School of Economics Library, Archives and Special Collections, NCLC. 
approaches' to institutional history, and it is important for historians of adult education to strive for a similar breadth and depth of purpose. ${ }^{34}$ In doing so, we should take advantage of the materials that are available, but in a way that recognises the limitations of a narrowly institutional approach.

\section{Approaches to the history of adult education}

Four suggestions follow for ways in which this might be done. They are by no means exhaustive, but they open up possibilities for more theoretically informed and methodologically sophisticated research in the history of education and, just as importantly, offer the possibility of fruitful contact with other areas of historical scholarship.

\section{Governance and educational institutions}

My first suggestion is informed by the large body of research on 'governance', both in educational settings and more widely across politics and society. Educational governance has been an important area of recent debate, especially in relation to higher education, but there is relatively little historical work in this area. ${ }^{35}$ There has, however, been considerable research on students in the past, some of which has touched on their participation in the governance of universities and on other political activities. This provides insights into perceptions of 'citizenship' and the role of what Eric Ashby and Mary Anderson called the 'student estate'. ${ }^{36}$ Debating societies and student unions have been important parts of university life; and just as the Oxford Union has served as the 'playground of power', as David Walter called it, other institutions have done the same for less educationally privileged adult learners. ${ }^{37} \mathrm{In}$ nineteenth-century Britain, when many, if not most, of the members and students of adult education institutions were not able to participate in formal political processes, their educational activities could be a substitute form of political engagement. As one adult learner recalled of the 1840s, when he was an active member of a Lancashire mutual improvement society, 'no members of the Imperial Parliament ever go with a prouder joy to their great House than we went on Saturday nights to our meetings. There was a hum, a bustle, and an interest when we first met, as if the fate of a nation depended on that night's debate. ${ }^{38}$ This raises intriguing questions about the political purposes of involvement in nineteenth-century adult education organisations, whose leaders, as Brian Simon showed in relation to mechanics' institutes, did not always permit overt political debate. ${ }^{39}$ There is also the important matter of internal governance. It has often been noted that 'self-government' was a

\footnotetext{
${ }^{34}$ Harold Silver, "'Things change but names remain the same": Higher Education Historiography 1975-2000', History of Education 35 (2006), 121.

${ }^{35}$ For an example dealing with higher education, see Catriona M. M. Macdonald, "“To form citizens": Scottish Students, Governance and Politics 1884-1948', History of Education, 38 (2009), 383-402.

${ }^{36}$ Eric Ashby and Mary Anderson, The Rise of the Student Estate in Britain (London: Macmillan, 1970). See also Georgina Brewis, A Social History of Student Volunteering: Britain and Beyond (New York: Palgrave Macmillan, 2014).

${ }^{37}$ David Walter, The Oxford Union: Playground of Power (London: Macdonald, 1984).

${ }^{38}$ Quoted in Michael I. Watson, 'Mutual Improvement Societies in Nineteenth-Century Lancashire, Journal of Educational Administration and History, 21(2) (1989), 15.

${ }^{39}$ Brian Simon, Studies in the History of Education (London: Lawrence \& Wishart, 1960), 153-9.
} 
preoccupation within workers' education, and that adult students' participation in the governance of educational institutions - of all kinds - was itself seen as part of a learning process. ${ }^{40}$ For R. H. Tawney and G. D. H. Cole, for example, liberal adult education was a 'microcosm' of the society that it existed to promote, and should be governed in the same way. As Lawrence Goldman has emphasised, there was a relationship between the ideas of self-government in the WEA and the 'democratic culture' of the Oxbridge college, and Basil Yeaxlee made a revealing comparison between Oxbridge common rooms and those of adult education institutions. ${ }^{41}$ These aspects of adult education would bear further examination.

While educational governance is a key area of contemporary interest, it has rarely been examined in as much depth historically, although there are some interesting insights in a 2001 article by Richard Willis, who showed how political metaphors surfaced in debates on the governance of the College of Preceptors, and explored in detail the internal political structures of the organisation. ${ }^{42}$ The students' strike at Ruskin College in 1909 has, of course, been discussed many times, ${ }^{43}$ but there have been many other such flashpoints in the history of education that may warrant examination from an historical perspective. ${ }^{44}$ The complex administrative structures of national educational organisations, which sometimes saw considerable tensions between the central authority and the localities, are important features of the history of adult education, and have been mentioned, though often only in passing, by many historians. ${ }^{45}$ I have argued elsewhere that the robust debates on the structure and governance of educational institutions reflected the wider political alignments of the protagonists, and in turn raised larger questions about the content and purpose of adult education. ${ }^{46}$ Similarly, John McIlroy, discussing trade union education, has insisted that what might appear to outsiders as 'largely questions of resource allocation' are in fact perceived by participants in the debates as 'important and fundamental differences of philosophy and interest ${ }^{,}{ }^{47}$ A critical perspective on the nature and activities of adult education institutions

${ }^{40}$ Geoffrey C. Fidler, 'Labor Conflicts in British Workers' Education in the Early Twentieth Century: A Local Perspective', Paedagogica Historica, 24 (1984), 51-82; Mark Freeman, "“An advanced type of democracy": Governance and Politics in Adult Education c.19181930', History of Education, 42 (2013), 63-4.

${ }^{41}$ Lawrence Goldman, Dons and Workers: Oxford and Adult Education since 1850 (Oxford: Oxford University Press, 1995), 300; Basil A. Yeaxlee, 'The Universities and the People', Contemporary Review, 120 (1921), 516-24.

${ }^{42}$ Richard Willis, 'Democratic Influence and Control in Educational Enterprise: DecisionMaking Processes within the College of Preceptors in the Mid-Nineteenth Century', Journal of Educational Administration and History 33 (2001), 17-29, esp. 19.

${ }^{43}$ REFERENCE TO PART I OF ARTICLE.

${ }^{44}$ For one avenue of further research, see Report of a Committee of Inquiry into the Problems at Fircroft College under the Chairmanship of Andrew Leggatt QC (London: HMSO, 1976). ${ }^{45}$ See for example Margaret Cohen, 'The Labour College Movement between the Wars: National and North-West Developments', in Brian Simon (ed.), The Search for

Enlightenment: The Working Class and Adult Education in the Twentieth Century (London: Lawrence and Wishart, 1990), 105-36; Mark Freeman, 'The Decline of the Adult School Movement between the Wars', History of Education, 39 (2010), 492-3; Mary Stocks, The Workers' Educational Association: The First Fifty Years (London: Allen and Unwin, 1953), 107-8, 113-14.

${ }^{46}$ Freeman, "“An advanced type of democracy".

${ }^{47}$ John McIlroy, 'Storm and Stress: The Trades Union Congress and University Adult Education', Studies in the Education of Adults, 20 (1988), 61. 
can be enhanced by a consideration of the distribution of power and authority, both formal and informal, within and beyond them - in both the present and the past. Investigating the ways in which rules were set and applied, and decisions taken, in educational institutions can illuminate their relationship to wider political and cultural histories. There is a large body of political and social theory in the area of governance, and, although much of it is open to challenge and further debate ${ }^{48}$ it certainly has the potential to strengthen the theoretical component of the historiography of adult education.

\section{Publications and student writing}

My second suggestion is a fairly simple one, but it offers the possibility of bringing together institutional histories of adult education and the flourishing history of reading and writing. Until now historians have paid less attention than is warranted to the publications of adult education institutions. Most organisations were well aware of the importance of their publications, and some historians have emphasised this: Stephen Roberts, for example, reminds us that the journal Highway was the 'permanent shop window' of the WEA. With a peak circulation of 20,000, it was known as 'the poor man's New Statesman' under the interwar editorship of W. E. Williams. ${ }^{49}$ Highway and the independent working-class education journal Plebs are both well known, and are where the debates between the two wings of workers' education 'crytallized'. ${ }^{50}$ Yet, although some work has been done by Stuart Marriott on the 'official' university extension publications, there remains scope for more detailed and sophisticated examination of the publications of many other adult education organisations, dating from the nineteenth century until the present. Few historians, for example, have exploited the adult school journal One and All, which can cast much light on the history of this important educational and religious movement, as well as on wider social and religious history. One and All was published from 1891 and had a circulation of 16,000 in 1918; and sometimes separate regional inserts were also issued. ${ }^{51}$ Other potentially useful publications include the ECA journals Common Room and, later, Phoenix; the Tutors' Bulletin, published by the Association of Tutors in Adult Education; and the various periodicals issued by the YMCA. ${ }^{52}$ The value of such publications to the historian is demonstrated by Tom Steele, who has used the Tutors' Bulletin and Highway to examine effectively the mid-twentieth-century debate in liberal adult education between 'class' and 'mass' culture ${ }^{53}$ Beyond these regular publications, there is a substantial pamphlet literature emanating from adult education organisations, often reflecting on the processes of education

\footnotetext{
${ }^{48}$ Anne Mette Kjær, Governance (Cambridge: Polity Press, 2004); Jonathan S. Davies, Challenging Governance Theory: From Networks to Hegemony (Bristol: Policy Press, 2011).

${ }^{49}$ Stephen K. Roberts, 'Introduction', in Stephen K. Roberts (ed.), A Ministry of Enthusiasm: Centenary Essays on the Workers' Educational Association (London: Pluto Press, 2003), 2, 8-9; John Atkins, "A Hard Rain's A-Gonna Fall”: The National Association and Internationalism', in Roberts, Ministry of Enthusiasm, 121; E. M. Richardson, 'Williams, Sir William Emrys (1896-1977)', rev., Oxford Dictionary of National Biography.

${ }^{50}$ Fidler, 'Labor Conflicts', 73. See also Atkins, "'Hard Rain”, 121.

${ }^{51}$ Hall, Adult School Movement, 33; Howard, Literacy, 94.

52 There is a complete run of Common Room in the UCL Institute of Education Archives, London. The YMCA's Red Triangle News, Scottish Manhood and other publications are in the National Archives of Scotland, Edinburgh.

${ }^{53}$ Tom Steele, The Emergence of Cultural Studies 1945-65: Cultural Politics, Adult Education and the English Question (London: Lawrence and Wishart, 1997), chapter 4.
} 
and its role in communities. There is also the opportunity to consider the teaching materials used in adult education. Again, the adult school movement has particularly good resources, with an annual Lesson Handbook containing guidance on particular areas of religious and social education. The status and content of the handbook was itself the subject of debate and conflict within the NASU. ${ }^{54}$ The study of textbooks is now a substantial area of research in the history of education: as John Issitt remarked in 2004, these sources offer 'rich pickings' for scholars interested in 'the construction, manipulation and reproduction of power and ideology'. ${ }^{55}$ There is also a large body of teaching material produced by the NCLC, a detailed study of which could enhance historical understandings of workers' education. ${ }^{56}$

Such sources can help to cast light on aspects of education, including specific practices, that are hidden from other parts of the archival record. It has been noted, for example, that study circles are a very murky area of educational history, but we can get some insights into them from the literature produced by organisations that supported such ventures. ${ }^{57}$ Beyond this literature that was issued at a national level were innumerable local publications. One example is Friendship, the publication of the Walthamstow Educational Settlement, whose first number appeared in 1930 and which continued until 1964. This contained contributions by the warden and tutors at the settlement, information on local activities, articles on matters of contemporary and historical interest, and letters from members of the student body. ${ }^{58}$ Another example is Cresset, produced by students at the City and Holloway Literary Institutes in the 1920s and 1930s; this contained students' poems and short stories, details of Institute activities, book reviews and short articles on various topics related and unrelated to adult education. ${ }^{59}$ Individual WEA branches produced their own publications, and the same is true of evening institutes, settlements, colleges, literary institutes and adult schools. There is much to be done to analyse such publications and the writing practices of adult students and their tutors. Recent years have seen a growing body of work on children's writing, such as Siân Pooley's study of 'children's columns' of provincial newspapers in the nineteenth and early twentieth centuries and Catherine Sloan's research on school magazines. ${ }^{60}$ Pooley suggests that 'the choices that writers made and the constraints around what they wrote [offer] insights ... into the shifting ways that young understood themselves and ... society'. ${ }^{61}$ There is certainly scope for similar insights into the world-view of adult students. In a few cases there is even some 'real-time' material written by students in adult education classes, such as the WEA tutorial class logbooks from four towns in Yorkshire, recently examined by

\footnotetext{
${ }^{54}$ Freeman, 'Decline of the Adult School Movement', 492.

55 John Issitt, 'Reflections on the Study of Textbooks', History of Education, 33 (2004), 688.

${ }^{56}$ See for example postal course material, Labour History Archive and Study Centre, Manchester, Acc.1416.

${ }^{57}$ Chase, "Mythmaking and Mortmain", 62; Tom Steele, Knowledge is Power! The Rise and Fall of European Popular Educational Movements 1848-1939 (Bern: Peter Lang, 2007), 189-91.

${ }^{58}$ There is an incomplete run of Friendship in Waltham Forest Archives, W.58.41/17.

${ }^{59}$ Seventeen volumes of Cresset are held in the British Library, general reference collection, P.P.6029.p.

${ }^{60}$ Siân Pooley, 'Children's Writing and the Popular Press in England 1876-1914', History Workshop Journal, 80 (2015), 75-98; Catherine Sloan, "'Periodicals of an objectionable character": Peers and Periodicals at Croydon Friends' School 1826-1875', Victorian Periodicals Review, 50 (2017), 769-86.

${ }^{61}$ Pooley, 'Children's Writing', 77.
} 
Kumbhat in her doctoral thesis. ${ }^{62}$ A close analysis of the contents of such published and unpublished material can shed light on the ways in which learners understood their educational experiences, and on debates within adult education, including some of the governance issues discussed above. Both the study of governance and an examination of the literature of adult education provide access to 'forums of debate' that might help historians to avoid the lack of 'subtlety' that has - at least according to Chase in 1995 - hitherto characterised the analysis of power relations in adult education. ${ }^{63}$

\section{Biographical studies of learners and teachers}

Both these approaches also illuminate the relationships between institutions and people, and this brings me to my third theme: the study of individuals and groups in adult education. One of the most notable developments within the history of education in recent years has been the widespread use of biographical and prosopographical research. Historians of education, particularly those concerned with gender and women's lives, have enthusiastically adopted the biographical approach, and in doing so have provided a series of methodological and theoretical insights informed by the tradition of 'life history' in adult education. ${ }^{64}$ It is not always possible to re-create as much of the biographies of adult learners as we would like although it is perhaps surprising that relatively little oral history of adult education has been done - but there is an abundance of material to help us to make sense of the 'educational lives' of many of those who shaped policy and practice in adult education, at both national and local levels. ${ }^{65}$ The importance of individual leadership was often commented upon within educational movements, and historians have echoed this theme. ${ }^{66}$ A good example of the biographical genre is Jane Martin's study of Mary Bridges Adams, much of which deals with adult education, and which, among other things, reminds us of the central and still often overlooked role played by women in workers' educational movements. ${ }^{67}$ Martin's reflections on the process of writing this biography emphasise the potential for biographical research to 'illuminate' the relationship between identity and action within specific contexts, and show that the study of particular individuals can provide helpful insights into the processes of education and its role within communities. ${ }^{68}$ From the learner's perspective, Feely's work on

\footnotetext{
${ }^{62}$ Kumbhat, 'Working Class Adult Education in Yorkshire', 209-49.

${ }^{63}$ Silver, Education as History, 100-1; Chase, "Mythmaking and Mortmain", 55.

${ }^{64}$ For a survey of biographical literature, see Jane Martin, 'Interpreting Biography in the [sic] History of Education: Past and Present', History of Education, 41 (2012), 87-102. See also Mark Freeman and Alice Kirke, 'Review of Periodical Literature on the History of Education Published in 2016', History of Education, 46 (2017), 840-3.

${ }^{65}$ In 2012 and 2013 the journal History of Education Researcher had a section entitled 'Educational Lives', but this was not sustained.

${ }^{66}$ See for example J. P. Hemming, 'The Mechanics' Institutes in the Lancashire and Yorkshire Textile Districts from 1850', Journal of Educational Administration and History, 9 (1977), 18-31; Freeman, “"An advanced type of democracy”, 64.

${ }^{67}$ Jane Martin, Making Socialists: Mary Bridges Adams and the Fight for Knowledge and Power 1855-1939 (Manchester: Manchester University Press, 2010).

${ }^{68}$ Jane Martin with John Kirk, Christine Wall and Steve Jefferys, 'Biography, Education and Civic Action: Teaching Generations and Social Change, in Margaret Wetherell (ed.), Theorizing Identities and Social Action (Basingstoke: Palgrave Macmillan, 2009), 38-55.
} 
Frank Forster is, again, an excellent example, although difficult to replicate given the possibly unique richness of the source material in the form of Forster's diary. ${ }^{69}$

There is, of course, a danger in focusing on increasingly obscure individuals in a quest to restore forgotten categories of people to the historical record. Fieldhouse warned in 1996 that 'the present enthusiasm for life histories ... may prove to be a pendulum swing too far obscuring the big picture ... with fine, meaningless detail' ${ }^{70}$ One way to avoid this problem is to locate the biographies of key figures within a larger study, as Goldman does in his book Dons and Workers. ${ }^{71}$ Another is to turn to collective biography, considering a small group of individuals, often connected, and to trace their mutual ideological inheritances and subsequent influences. A good example of this is the work of Robert Hamilton and Robert Turner on the 'linked biographies' of Edward Caird, Henry Jones, A. D. Lindsay and Hector Hetherington, all of whom occupied the chair in moral philosophy at the University of Glasgow and all of whom had a strong commitment to adult education due to the influence of Hegel on their social and educational thought. ${ }^{72}$ Some recent studies of individuals and groups in the history of second-wave feminism also emphasise the educational work of key activists and their networks, as well as informal educational institutions such as publishing houses and bookshops. ${ }^{73}$ As suggested above, collective biography can also be done, usually in a more limited way, with students: a good example of this is the recent prosopographical work by Joyce Goodman and others using the registers of Cambridge women's colleges to illustrate aspects of 'cultural transmission'. ${ }^{74}$ The publications of adult education institutions are excellent sources of biographical information, not least because they often carried obituaries of otherwise obscure figures.

Perhaps the most productive theoretical context in which to approach collective educational biography is through Karl Mannheim's ideas about 'generations', first published in 1952. It has been pointed out that, despite the widespread use of life history methods in adult education, research on generations has been largely neglected. ${ }^{75}$ Martin and others have used Mannheim's insights to frame their study of 'teacher identity' across four different periods, and pointed out that the generations concept has similarities to Raymond Williams's notion of a 'structure of feeling' shared by a particular cohort of people. ${ }^{76}$ In one useful

\footnotetext{
${ }^{69}$ Feely, 'From Dialectics to Dancing'.

${ }^{70}$ Fieldhouse, "Mythmaking and Mortmain", 119.

${ }^{71}$ See his chapter on Arthur Acland, Arnold Toynbee and T. H. Green: Goldman, Dons and Workers, 37-60.

${ }^{72}$ Robert Hamilton and Robert Turner, 'Hegel in Glasgow: Idealists and the Emergence of Adult Education in the West of Scotland 1866-1927', Studies in the Education of Adults 38 (2006), 195-209.

73 Phillida Bunkle, 'The 1944 Education Act and Second Wave Feminism', Women's History Review 25 (2016), 791-811; Lucy Delap, 'Feminist Bookshops, Reading Cultures and the Women's Liberation Movement in Great Britain, c. 1974-2000', History Workshop Journal 81 (2016), 171-96; Miriam E. David, 'Feminism, Activism and Academe: A Personal Reflection, Women's History Review 25 (2016), 983-98.

${ }^{74}$ Joyce Goodman, Andrea Jacobs, Fiona Kisby and Helen Loader, 'Travelling Careers: Overseas Migration Patterns in the Professional Lives of Women Attending Girton and Newnham before 1939', History of Education, 40 (2011), 179-96.

75 John Field with Heather Lynch and Irene Malcolm, Generations, the Life Course and Lifelong Learning, Learning Lives Summative Working Paper, no. 3. (Exeter: Learning Lives, 2008), 17.

${ }^{76}$ Martin et al, 'Biography', 38-9.
} 
definition, a generation 'consists of a group of people born during the same time period and who are united by similar life experiences and a temporarily coherent cultural background'. ${ }^{77}$ In educational terms, successive generations might interpret the mission of adult education, for example, in different ways, reflecting their shared experiences. In the historiography of adult education the generations approach explicitly underpins Stephen Woodhams's study of the generation of radical intellectuals who lived through the 1930s and, through adult education, reshaped the academic study of history and culture. ${ }^{78}$ Similar insights into the experience of the same generation - and a closer attention to the vital importance of gender in this context - are available from Tom Steele's 1997 book The Emergence of Cultural Studies. ${ }^{79}$ There are few if any educational 'movements' whose historiography would not benefit from a clearer consideration of the impact of generational change.

These studies largely depict the experience of teachers and leaders in adult education, but it is also possible to deploy collective biographical approaches to examine the experiences of adult learners. Even where records are scanty, there are opportunities to gain illuminating insights into the composition and backgrounds of groups of adult learners. Sarah Speight, for example, has has used the first names of students in a Derbyshire WEA local history class in the 1940s to estimate the age groups involved: the Ellens, Ethels and Claras predominated, with the younger Janets and Lindas in a minority ${ }^{80}$ For the nineteenth century in particular, record linkage offers opportunities to examine the demographics of adult education in a more sustained way, and although this research is painstaking and can yield only partial results, it allows for the tracing of individuals and their educational and career trajectories over time. Given the relative silence of adult education students in the archival record, historians need to take every possible opportunity of throwing some light on the part that adult education played in people's lives, and this could be promising territory for the historian to explore. Indeed, it could be argued that it is essential: Michael Sanderson commented in 2007 that '[n]o serious history of an educational institution would now neglect some attempt to study the career outcomes of their [sic] students. ${ }^{, 81}$ There have been some attempts to quantify the relationship between elementary education and social mobility, the most significant being the work of Jason Long, who has shown that schooling did have an effect on nineteenth-century labour market outcomes, though less than in modern times. ${ }^{82} \mathrm{We}$ need not fully endorse the somewhat over-optimistic comments of the American historian Geraldine Jonçich Clifford - ' $[\mathrm{t}]$ hrough analysis of records like federal manuscript census ... quantitative historiography is able to bring massive inclusiveness and awesome precision to the question of who went to school' ${ }^{83}$ - but we can still recognise the potential of studies

${ }^{77}$ Ari Antikainen, Jarmo Houtsonen, Juha Kauppila and Hannu Huotelin, Living in a Learning Society: Life Histories, Identities and Education (London: Routledge, 1996), 34, quoted in Field et al, Generations, 13.

${ }^{78}$ Stephen Woodhams, History in the Making: Raymond Williams, Edward Thompson and Radical Intellectuals 1936-1956 (London: Merlin Press, 2001).

${ }^{79}$ Steele, Emergence of Cultural Studies.

${ }^{80}$ Sarah Speight, 'Localising History 1940-1965: The Extra-Mural Contribution', Journal of Educational Administration and History, 35 (2003), 55-6.

${ }^{81}$ Michael Sanderson, 'Educational and Economic History: The Good Neighbours', History of Education, 36 (2007), 440.

82 Jason Long, 'The Socioeconomic Return to Primary Schooling in Victorian England', Journal of Economic History, 66 (2006), 1026-63.

${ }^{83}$ Geraldine Jonçich Clifford, 'History as Experience: The Uses of Personal-History Documents in the History of Education', History of Education, 7 (1978), 190. 
based on record linkage. C. J. Radcliffe noted the possibility of tracing members of mutual improvement societies in the nineteenth-century census in $1986,{ }^{84}$ and a decade later David Coppock used the census enumerators' books and teachers' record cards to show the gendered nature of social mobility among pupil teachers in the late nineteenth and early twentieth century. ${ }^{85}$ As noted in Part I of this article, ${ }^{86}$ a distinction is often drawn between social and individual motivations for participation in adult education, but it is clear that some educational opportunities offered individual benefits, even if these were not the main reason for taking advantage of them. Adult education might have a range of 'outcomes', for the individual as well as the community.

\section{The spaces and places of adult education}

A fourth productive area of research could address the historical geographies and material cultures of adult education, including the history of buildings and outdoor spaces.

Contemporary educational scholarship pays a lot of attention to space and place, reflecting a 'spatial turn' that has also had a profound influence on historical research. There is already a rich vein of architectural history of education, focusing on school, college and university buildings. ${ }^{87}$ This could certainly be developed further in relation to the spaces in which adult education has been pursued: how was space used and understood, and what did buildings, and spaces within them, 'mean' to those who learned there? Speight has briefly examined these questions in relation to the University of Nottingham's 'venerable' adult education centre in Shakespeare Street, which closed in 2010: the building was an integral aspect of the educational experience for many of those who worked and studied in it, fostering (and sometimes restricting) learning and supporting a range of interpersonal relationships. ${ }^{88} \mathrm{Such}$ issues can relate to those of governance discussed above: as one recent contribution has noted, 'spatial analysis ... can offer an effective means of exploring ... the interaction between social processes at different scales'. ${ }^{89}$ Again, the common room, as emphasised by Yeaxlee, could be a space worthy of further examination in this context. There is scope for relating spatial history to sensory history: a striking recent example by Sian Vaughan, considering the Birmingham School of Art, appeared in History of Education in 2018. ${ }^{90}$ Museums and galleries are another site of 'informal' education in which the relationship between space and pedagogy is explored widely in contemporary research, but where there is scope for much further research from a historical perspective - this is potentially yet another

\footnotetext{
${ }^{84}$ C. J. Radcliffe, 'Mutual Improvement Societies in the West Riding of Yorkshire 18351900', Journal of Educational Administration and History, 18(2) (1986), 2.

${ }^{85}$ David A. Coppock, 'Respectability as a Prerequistite of Moral Character: The Social and Occupational Mobility of Pupil Teachers in the Late Nineteenth and Early Twentieth Centuries', History of Education 26 (1997), 165-86.

${ }^{86}$ REFERENCE TO PART I OF ARTICLE.

${ }^{87}$ See for example Catherine Burke, A Life in Education and Architecture: Mary Beaumont Medd (Farnham: Ashgate, 2013).

${ }^{88}$ Sarah Speight, " "I fell in love with the building", Adults Learning, 24/1 (2012), 32-5.

${ }^{89}$ Rachel Brooks, Alison Fuller and Johanna Waters, 'Changing Spaces of Education: An Introduction', in Changing Spaces of Education: New Perspectives on the Nature of Learning, ed. Rachel Brooks, Alison Fuller and Johanna Waters (London: Routledge), 4. ${ }^{90}$ Sian Vaughan, 'Art and Sonic Mining in the Archives: Methods for Investigating the Wartime History of Birmingham School of Art', History of Education, 47 (2018), 225-40.
} 
way in which historians of education can make links with scholars working on other aspects of the past. ${ }^{91}$ The same goes for the uses of outdoor spaces of adult education. ${ }^{92}$

It is also through a spatial lens that historians of education can explore the spread of knowledge and thought in the past, using network theory and focusing on both national and transnational knowledge networks. Importantly, such work develops the links between histories of education and intellectual history, and can also be related to the collective biographical approach discussed above. It is not necessary here to discuss in detail the large body of scholarship, much of it published in this journal, on educational networks in the past,${ }^{93}$ but it is worth noting the potential for further studies of transnational adult education initiatives as well as the history of educational travel, particularly where focused on the perspectives of learners. ${ }^{94}$ Again, travel was often undertaken through institutions, and so this learner-focused approach would not necessitate the abandonment of institution-focused study. There are many other possibilities for productive research through the lens of place: the knowledge networks created and sustained by voluntary organisations in nineteenth-century Britain, the spatial dimensions of learner identities that were performed (literally) in plays and pageants staged by adult education institutions, and the adult education dimensions of the 'political, social, and educational cultures of self-help and protest' among the West Indian community in the twentieth century, which Jess Gerrard has explored in her work on black supplentary schools for children; examples could be multiplied. ${ }^{95}$ Contemporary scholarship has some useful models for historians interested in knowledge networks and educational spaces: one example is Sue Jackson's study of identity formation within the geographical and social space of post-colonial London, focusing on Asian 'migrant women' ${ }^{96}$ Jackson shows how formal and informal education offers spaces for migrant women to 'network with others and affirm identities': they participate in knowledge exchange and shape their own self-

${ }^{91}$ See for example Janna Graham, "“Where are we when we think?" Space, Time and Emancipatory Education in Galleries', International Journal of Lifelong Education, 37 (2018), 21-39. For an historical perspective on museums and informal education, see Clara Cullen, 'The Museum of Irish Industry, Robert Kane and Education for All in the Dublin of the 1850s and 1860s', History of Education, 38 (2009), 99-113.

${ }^{92}$ See for example Ben Anderson, 'Partnership or Co-operation? Family, Politics and Strenuousness in the Pre-First World War Co-operative Holidays Association', Sport in History, 33 (2013), 260-81.

${ }^{93}$ For a survey, some years ago, see Eckhardt Fuchs, 'Networks and the History of Education', Paedagogica Historica, 43 (2007), 185-97.

${ }^{94}$ See for example Anderson, 'Partnership or Co-operation?'; Marcella Pellegrino Sutcliffe, 'The Toynbee Travellers' Club and the Transnational Education of Citizens 1888-90', History Workshop Journal, 76 (2013), 137-59; Neil Matthews, 'The Very Model of a Modern Travel Agency? The Polytechnic Touring Association 1888-1962' (unpublished PhD thesis, University of Westminster, 2015).

${ }^{95}$ Angela Bartie, Linda Fleming, Mark Freeman, Tom Hulme, Alexander Hutton and Paul Readman, "History taught in the pageant way": Education and Historical Performance in Twentieth-Century Britain', History of Education, 48 (2019), 156-79; Jess Gerrard, 'Self Help and Protest: The Emergence of Black Supplementary Schooling in England', Race, Ethnicity and Education, 16 (2013), 35. See also the ongoing project led by Heather Ellis and funded by the Fritz-Thyssen Stiftung, Cologne: 'Literary and Philosophical Societies in Britain and Germany 1760-1918'.

${ }^{96}$ Sue Jackson, 'Learning through Social Spaces: Migrant Women and Lifelong Learning in Postcolonial London', International Journal of Lifelong Education, 29 (2010), 237-53. 
perception as learners and members of communities. ${ }^{97}$ There are potentially productive links here with the biographical approach discussed above. The opportunities for historians to consider learner identities and knowledge networks, in different periods and using different sources including the learner-produced material that survives, are considerable.

\section{Conclusion}

There remains, then, much scope for innovative and original research on the history of adult education in Britain, building on the recent broadening of interest in the subject. In this twopart article I have suggested, either implicitly or explicitly, some particular areas where the history of adult education might intersect with other fields of historical inquiry, notably religious history, urban history, military history, political history, economic and business history, the history of literacies and the book, and, not least perhaps, the burgeoning historiography of "voluntary action'.$^{98}$ In addition, as Gary McCulloch has argued for the history of education more widely, there is also scope for historians of adult education to engage productively with sensory history, the history of the emotions, histories of leisure and much else. ${ }^{99}$ These opportunities suggest that neither adult education nor its history should be seen as marginal, though this has been a feature of both historical and sociological perspectives on it. Nevertheless, there is no doubt that a sense their own marginality has often conditioned the ways in which adult education leaders have behaved. This was a central theme of the British historiography of adult education, especially in relation to the 'Great Tradition'. Recent developments, not unreasonably, have added to the sense of an adult education sector under siege and a tradition in further retreat. ${ }^{100}$ Taking a wider perspective, however, adult education is far from marginal. More than a fifth of adults in the UK participate in some kind of learning activity, with two-fifths reporting participation during the past three years. ${ }^{101}$ The eclectic range of provision available to these millions of learners offers an opportunity to think historically about the nature of adult learning in the past. Much of what is done in adult education relates to other areas of social and cultural life that are the central concerns of modern historical scholarship: religious and political activity, leisure pursuits, local and national identities, and community activitism. New perspectives on these areas of experience - in both the present and the past - can be gained by viewing them

${ }^{97}$ Ibid., 248.

${ }^{98}$ For an important contribution to the history of voluntary action, see Colin Rochester, George Campbell Gosling, Alison Penn and Meta Zimmeck (eds.), Understanding the Roots of Voluntary Action: Historical Perspectives on Current Social Policy (Brighton: Sussex Academic Press, 2011).

${ }^{99}$ Gary McCulloch, The Struggle for the History of Education (London: Routledge, 2011); Gary McCulloch, 'Sensing the Realities of English Middle-Class Education: James Bryce and the Schools Inquiry Commission', History of Education, 40 (2011), 599-613.

${ }^{100}$ One example is the closure of the Vaughan Centre for Lifelong Learning at the University of Leicester, the successor to the nineteenth-century Vaughan College, in 2016. A more encouraging development, however, is the emergence of Leicester Vaughan College, a cooperative community benefit society, offering university-level education to part-time and adult students. See https://vaughan.coop/ (accessed 20 January 2019).

101 '2015 NIACE Adult Participation in Learning Survey: Headline Findings':

http://www.learningandwork.org.uk/sites/niace_en/files/resources/2015\%20Adult\%20Partici pation\%20in\%20Learning\%20-\%20Headline\%20Findings.pdf?redirectedfrom=niace (accessed 20 January 2019). 
through the lens of adult education, and this is turn can help historians of education to make closer connections with scholars working on other aspects of history. This can, and should, present us with opportunities to expand and revitalise the history of adult education.

\section{Acknowledgements}

I am grateful to Heather Ellis and Pushpa Kumbhat, as well as three anonymous reviewers, for helpful comments on earlier drafts of this article. 